\title{
Effect of rice husk ash (RHA) on the properties of Ibaji burnt clay bricks
}

\author{
Agbede, I. O, and Joel, M \\ Department of Civil Engineering, University of Agriculture, Makurdi, Nigeria. \\ femiagbede2002@yahoo.com and manassehjoel@yahoo.com
}

\begin{abstract}
A study was undertaken to investigate the effects of rice husk ash (RHA) on the burnt properties of the clay brick. 2 to $10 \%$ RHA was blended with the clay. Atterberg limits, specific gravity, compressive strength and water absorption tests were conducted on each admixture. In addition, $X$-ray diffraction and geochemical tests were performed on the soil and rice husk ash respectively. $X$-ray diffraction study showed that Ibaji soil was mainly kaolinite. The results showed that the plasticity index reduced gradually and had a minimum value at $6 \%$ RHA. The compressive strength and water absorption attained a maximum value of $18.64 \mathrm{MN} / \mathrm{m}^{2}$ and a minimum value of $14.8 \%$ respectively at $2 \%$ RHA. Thus $2 \%$ RHA additive led to a significant improvement in the properties of Ibaji burnt clay brick.
\end{abstract}

Keywords: Rice husk ash, Compressive strength, Clay brick

\section{INTRODUCTION}

There is a wide range of material available for the construction industries. The choice and sustainability of a particular material depends largely on its availability, nature of project, individual preference, durability, proximity and economic consideration.

Rice husk ash (RHA) is obtained from the burning of rice husk. The husk is a by-product of the rice-milling industry. By weight, $10 \%$ of the rice grain is rice husk. On burning the rice husk about $20 \%$ becomes RHA (Mehta, 1986).

Several researchers have studied possible ways of making rice husk for block moulding and building construction. These studies were based on the growing cost of lime and cement, traditional stabilizing agents, coupled with the need for the economic utilization of industrial and agricultural wastes for beneficial engineering purposes. Thus the possible use of RHA as an additive to soil for brick production in agrarian communities will reduce or eliminate the environmental hazards caused by such waste.

Oriola and Moses (2010) explored the use of groundnut shell ash to stabilize black cotton soil and reported that the attempt was futile.

To produce good quality bricks, various additives have been used by different researchers such as rice husk (Pepplinkhouse, 1980; Ibanga and Ahmed, 2007), rice husk ash (Rahman, 1988) and sawdust (Okongwu, 1988). Okongwu (1988) showed that at relatively small concentrations $2 \%$ by weight of sawdust additive greatly enhanced the properties of burnt brick and that additives above $3 \%$ by weight were found to be deleterious. Ibanga and Ahmed (2007) concluded that the two most important properties of burnt bricks, namely compressive strength and water absorption can be improved substantially by adding rice husks.

Bricks are classified by both the average or minimum compressive strength and the percentage water absorption. According to this classification, minimum compressive strength of bricks should be $3.5 \mathrm{MN} / \mathrm{m}^{2}$ and the water absorption should not exceed $20 \%$. (Brick Development Association, 1974; IS 1077. 1992).

The ASTM C 62 - 97 specification for building bricks sets $20.7 \mathrm{~N} / \mathrm{mm}^{2}, 17.2 \mathrm{~N} / \mathrm{mm}^{2}$ and $10.3 \mathrm{~N} / \mathrm{mm}^{2}$ as the minimum fired compressive strengths for Grade SW (severe weather), Grade MW (moderate weather) and Grade NW (negligible weather) bricks respectively.

The objective of this study is to examine the effects of rice husk ash on the properties of Ibaji clay when used in the production of bricks.

\section{MATERIALS AND METHODS}

The soil used for this study was collected from EjuleOjebe in Ibaji Local Government Area of Kogi State. It was collected from a pit about $1 \mathrm{~m}$ deep near the bank of the river. It was dug and excavated with the aid of a hoe. The rice husk ash was collected from 
the heap of rice husk being burnt by the river side at the Rice Mill in Wadata, Makurdi. The soil has been employed, without prior milling for the production of hand-moulded burnt bricks.

The following tests were performed on the natural sample and the soil-rice husk ash admixtures, natural moisture content, Atterberg limits, grain size analysis, specific gravity and compaction. All the tests were performed in accordance with the British standard specification. B.S 1377 (1990).

Different percentages of RHA (2, 4, 6, 8 and 10 of dry weight of soil) was thoroughly mixed with clay and a graded addition of water until approximately the optimum moisture content as determined during compaction. This gave a good moulding consistency and there after molded into brick each measuring $40 \mathrm{~mm} \times 40 \mathrm{~mm} \times 40 \mathrm{~mm}$. Using a caste ion mold cavity and compressed under $15 \mathrm{MN} / \mathrm{m}^{2}$ pressure using a compression machine. The molded brick was extruded by loosening the mold and carefully removing the brick. The brick was cured at room temperature for 12 days prior to burning.

Three bricks were moulded from each admixture. After careful drying and curing at room temperature, the bricks were subsequently fired in an electric muffle furnace with a rise of $200{ }^{\circ} \mathrm{C} / \mathrm{h}$ and a 4 hour soak at $800{ }^{\circ} \mathrm{C}$.

The compressive strength of each brick was determined in accordance with the Specification of the Standard Organization of Nigeria (SON) as contained in Test for Compressive Strength of Solid Bricks using the Testing Machine.

A $40 \mathrm{~mm}$ square platen was used on the compressive testing machine. Three test cubes were preconditioned by immersion in cold water at room temperature $\left(29{ }^{\circ} \mathrm{C} \pm 2{ }^{\circ} \mathrm{C}\right)$ for 24 hours, removed and all traces of water wiped off, and then stored under moist conditions for 24 hours prior to testing. Each test piece was centrally positioned between the platens of the testing machine, and the load was gradually increased until failure.

The water absorption test was performed by a " 24 hour immersion in cold water" as specified by the Standard Organization of Nigeria. Three cubes were preconditioned by drying in a ventilated oven at $10^{\circ} \mathrm{C}$ until it attained constant mass and then cooled to room temperature and weighed to note its initial weight $\mathrm{M}_{1}$. The precondition test piece was immersed in cold water at room temperature $\left(29^{\circ} \mathrm{C} \pm 2\right)$ for 24 hours and thereafter removed and any traces of water wiped off. The test piece was then weighed to note its increased weight $\mathrm{M}_{2}$. The water absorption, defined as the relative increase in weight, was thus calculated. The test was conducted on three test pieces for each admixture composition.

\section{RESULTS AND DISCUSSIONS}

Figure 1 shows the particle size distribution of Ibaji clay. Figure 2 shows the variation of liquid limit, plastic limit and plasticity Index with different percentages of RHA. The relationship between the liquid limit and RHA did not follow any discernible trend but the plastic limit generally increased with increase in RHA content. This may be due to addition of RHA which led to the reduction in the quantity of free silt and clay fraction by forming coarser materials with larger surface areas; which require more water.

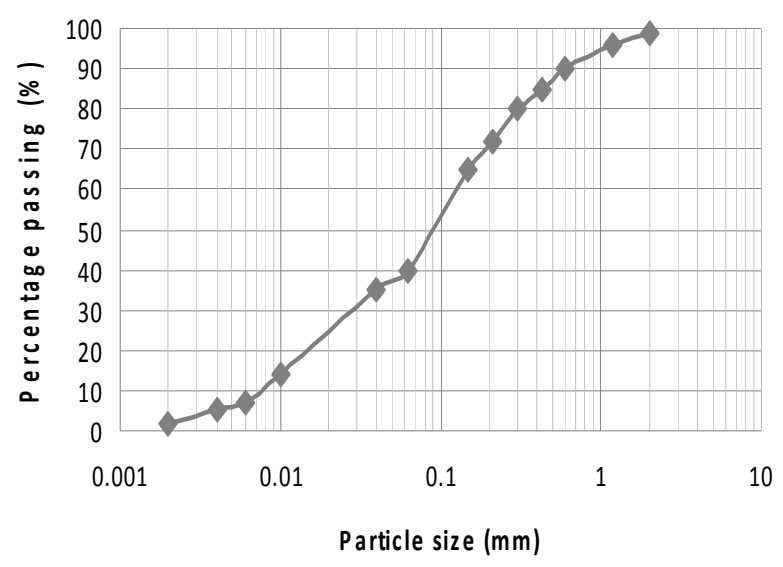

Figure 1 Particle S ize Dis tribution of Ibaji C lay.

The plasticity index decreased from $20.3 \%$ at $0 \%$ RHA to a minimum value of $6.5 \%$ at $6 \%$ RHA. A decrease in plasticity index is a sign of improvement of the soil.

Table 1 summarizes the results of tests. The linear shrinkage decreased from $10.0 \%$ for the natural soil sample to a minimum value of $7.9 \%$ at $6 \% \mathrm{RHA}$ and then remained constant. It appears that no further gain in volume stability is achieved beyond $6 \%$ RHA. 


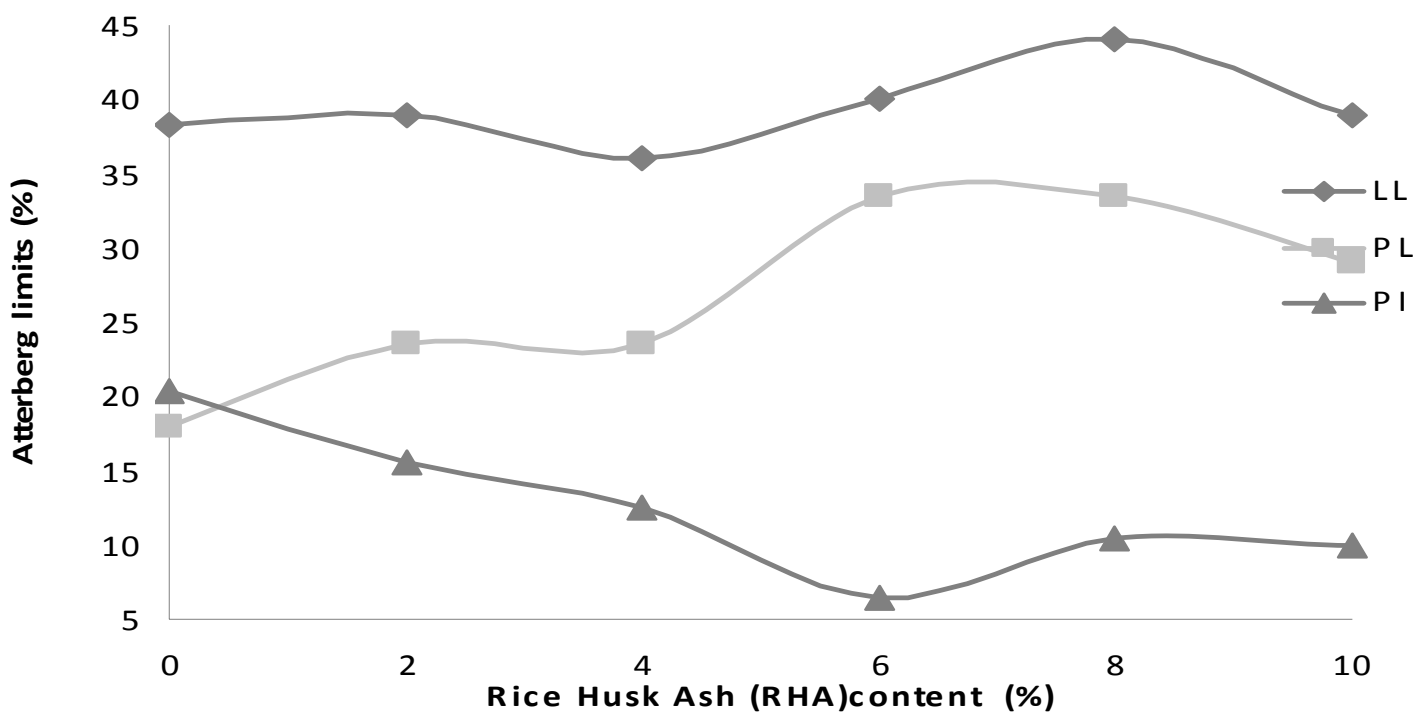

Fig ure 2 Relationship between Atterberg limits and R HA content (\%)

Table 1: Summary of test results

\begin{tabular}{|c|c|c|c|c|c|c|c|}
\hline RHA (\%) & LL (\%) & PL (\%) & PI (\%) & LS (\%) & $\begin{array}{c}\text { Specific } \\
\text { Gravity }\end{array}$ & $\begin{array}{c}\text { Compressive } \\
\text { Strength } \\
\text { (MN/m } \mathbf{2}^{2}\end{array}$ & $\begin{array}{c}\text { Water } \\
\text { Absorption } \\
\text { (\%) }\end{array}$ \\
\hline 0 & 38.3 & 18.0 & 20.3 & 10.0 & 2.42 & 17.60 & 16.8 \\
\hline 2 & 39.0 & 23.5 & 15.5 & 9.7 & 2.40 & 18.64 & 14.8 \\
\hline 4 & 36.0 & 23.5 & 12.5 & 9.3 & 2.40 & 16.13 & 16.0 \\
\hline 6 & 40.0 & 33.5 & 6.5 & 7.9 & 2.38 & 14.66 & 17.8 \\
\hline 8 & 44.0 & 33.5 & 10.5 & 7.9 & 2.37 & 10.26 & 19.2 \\
\hline 10 & 39.0 & 29.0 & 10.0 & 7.9 & 2.35 & 6.93 & 19.0 \\
\hline
\end{tabular}

The specific gravity of the RHA was found to be 2.04 while that of clay was found to be 2.42 . Therefore the addition of RHA to the soil led to a reduction in the specific gravity of the admixture.

Table 2 shows the geochemical composition of Ibaji clay and RHA. Results showed that Ibaji clay contained mainly silica (28.65\%) which is below the range of $55-75 \%$ for fireclays; alumina content is $31.42 \%$ which is within the range of $25-45 \%$ for fireclays. The oxide composition of RHA showed that it contained negligible percentage of aluminium oxide, $49.8 \%$ of silica and $14.3 \%$ of calcium oxide and negligible quantity of other oxides.
Table 2 Geochemical Composition of Ibaji Clay and RHA

\begin{tabular}{|c|c|l|}
\hline Element & $\begin{array}{l}\text { Ibaji Clay } \\
\text { (\%) }\end{array}$ & $\begin{array}{l}\text { RHA } \\
\text { (\%) }\end{array}$ \\
\hline $\mathrm{CaO}$ & 9.73 & 14.3 \\
\hline $\mathrm{MgO}$ & 3.97 & 13.7 \\
\hline $\mathrm{Fe}_{2} \mathrm{O}_{3}$ & - & 4.6 \\
\hline $\mathrm{SiO}_{2}$ & 28.65 & 49.8 \\
\hline $\mathrm{MnO}_{\mathrm{Al}} \mathrm{O}_{3}$ & 2.37 & 2.9 \\
\hline $\mathrm{TiO}_{2}$ & 31.42 & - \\
\hline $\mathrm{Na}_{2} \mathrm{O}$ & - & - \\
\hline $\mathrm{K}_{2} \mathrm{O}$ & 0.16 & 4.8 \\
\hline $\mathrm{P}_{2} \mathrm{O}_{5}$ & 0.08 & 2.1 \\
\hline $\mathrm{L}_{2} \mathrm{O} . \mathrm{I}$ & 0.03 & 1.5 \\
\hline & 23.59 & 6.3 \\
\hline
\end{tabular}


It is of particular note that the compressive strength of the bricks decreased as the amount of RHA substituted into the Ibaji clay increased. Maximum compressive strength of $18.64 \mathrm{MN} / \mathrm{m}^{2}$ was obtained at $2 \% \mathrm{RHA}$ and decreased to a value of $6.93 \mathrm{MN} / \mathrm{m}^{2}$ at $10 \%$ RHA. According to ASTM specification, bricks made with $0-2 \%$ RHA can be classified as MW grade while those made with 4-8\% RHA can be classified as NW grade.

The water absorption characteristics of the bricks showed that minimum water absorption of $14.8 \%$ was obtained for bricks made with $2 \%$ RHA compared to $16.8 \%$ water absorption for plain brick. The maximum value of $19.2 \%$ was obtained for bricks made with $8 \%$ RHA which was less than $20 \%$ prescribed in the standard.

The increase in compressive strength of the bricks from $17.60 \mathrm{MN} / \mathrm{m}^{2}$ at $0 \% \mathrm{RHA}$ to $18.64 \mathrm{MN} / \mathrm{m}^{2}$ at 2 $\%$ RHA might have been caused by the presence of $\mathrm{CaO}$ in RHA in very small quantity which reacted with the soil to form silicate of calcium at the introduction of water and subsequent composition and curing. Excess of the RHA in the clay may not have the opportunity to do this. Therefore, weakening the interparticles bonding that could have been formed by the soil particles. This was probably responsible for the increased water absorption obtained during the water absorption test, or it might be explained that during vitrification at $800{ }^{\circ} \mathrm{C}$ that the malting temperature of rice husk ash and that of the clay differed thereby resulting to a heterogeneous compound whose strength diminished with increase RHA and water absorption increased with increase in RHA.

\section{CONCLUSIONS}

The test results showed that more than $90 \%$ of the particles of Ibaji clay passed through the BS Sieve Number 200. The values of liquid limit and plastic limit at zero percent stabilization were found to be $38.3 \%$ and $18.0 \%$ respectively. The plasticity index was found to be $20.3 \%$. As the RHA increased, the liquid limit increased to a maximum value of $44 \%$ at 8 $\%$ RHA. The minimum liquid limit of $36 \%$ occurred at $4 \%$ RHA. The plastic limit also increaed with increase in RHA content, while the plasticity index reduced considerably. The reduction in plasticity index and shrinkage limit suggests a reduction in swell potential. It is therefore recommended that $2 \%$ $\mathrm{RHA}$ can be used to enhance the properties of Ibaji clay.
X-ray diffraction test showed that Ibaji soil to be mainly kaolinite.

The water absorption and compressive strength characteristics showed some improvement with $2 \%$ RHA. The strength of the brick was maximum at this point, with a compressive strength value of 18.64 $\mathrm{MN} / \mathrm{m}^{2}$ which is suitable for load bearing walls. At this point also, the lowest water absorption value was obtained with a value of $14.8 \%$. Therefore Ibaji clay can be used for brick production with or without additives. However an addition of $2 \%$ RHA can be recommended to improve the properties of the burnt clay bricks.

\section{REFERENCES}

BS 1377 (1990), "Methods of testing soils for civil engineering purpose" British Standard Institution, London.

BS 1924 (1990), Methods of Testing for Stabilized Soil. British Standard Institution, London.

Ibanga, E. J. and Ahmed, A. D. (2007). Influence of particle size and firing temperature on burnt properties of rice/clay mix. Pacific Journal of Science and Technology. 8(2): 267-271.

IS 1077. (1992). Indian standard: common burnt clay building bricks - specification. 5th Edition". BIS. New Delhi.

Mehta, P. K. (1986). Concrete structure, properties and materials. Prentice - Hall, Eaglewood Cliffs, N.J.

Nigerian Standard Organization: Specification for burnt clay building units. Nigeria Industrial Standard 74, 1976 UDC 624 0128. Federal Ministry of Industries, Lagos, Nigeria.

Okongwu, D. A. (1988). Effects of additive on the burnt properties of clay bricks. ceramic Bulletin,. 67(8):1409 $-1411$.

Oriola, F. and Moses, G. (2010). Groundnut shell ash stabilization of black cotton soil. Electronic Journal of Geotechnical Engineering. 15(E):415-428.

Pepplinkhouse, M. J. (1980), Utilization of rice hulls in brick-making: an industrial trail" J. Australian Ceram. Soc. 16: $26-28$.

Rahman, M. A. (1988). Effect of rice husk ash on the properties of bricks made from fires lateritic soil-clay mix. Materials and Structures. 21: 222-227.

The Brick Development Association (1974). Bricks, their properties and use. Construction Press Limited. 